\title{
Molecular detection of $\beta$-lactamases and aminoglycoside resistance genes among Escherichia coli isolates recovered from medicinal plant
}

\author{
Aleisa, A. M. ${ }^{1}$, Ashgan, M. $\mathrm{H}^{2}{ }^{2}$, Alnasserallah, A. A. ${ }^{2}$, Mahmoud, $\mathbf{M} . \mathrm{H}^{3}$ and Moussa, I. $\mathrm{M}^{4}$ \\ ${ }^{1}$ Department of Pharmacology, College of Pharmacy, King Saud University, Saudi Arabia. \\ ${ }^{2}$ College of Applied Studies and Community Services, King Saud University, Saudi Arabia. \\ ${ }^{3}$ Deanship of Scientific Research, King Saud University, Riyadh, Saudi Arabia. \\ ${ }^{4}$ Department of Botany and Microbiology, College of Science, King Saud University, P.O. Box 2455- Riyadh Kingdom of \\ Saudi Arabia. \\ Accepted 3 May, 2013

\begin{abstract}
Cross contamination from composting farm manure and surface run-off waters or the application of untreated sewage, or manure can be sources of pathogenic microorganisms that contaminate fruits and vegetables in the field. Therefore, the current study was aimed to detect the incidence of Escherichia coli isolates from herbs samples and the molecular detection of $\beta$-Lactamases and aminoglycoside resistance genes among $E$. coli isolates recovered from medicinal plant. 58 strains of $E$. coli $(28.43 \%)$ were isolated and serotyping of the recovered E.coli isolates revealed 18 strains $0125(31.03 \%), 12$ strains were $(20.69 \%)$ 086, 10 strains were $(17.24 \%)$ 0112, 8 strains were $(13.79 \%) 0127,6$ strains were $(10.34 \%) 0128$ and 4 strains were $(6.90 \%) 044$. The $E$. coli isolates were tested by PCR for detection of aacC2 gene; all isolates showed amplification of $896 \mathrm{bp}$ fragments specific for aacC2 gene. Multiplex PCR showed amplification of 516 bp fragments specific for blaTEM gene in all isolates (100\%). Moreover, 38 of the $E$. coli isolate (65.52\%) had a band compatible with blaSHV gene (392 bp fragments) while, the presence of blaOXA_1 gene was not detected in all $E$. coli isolates.
\end{abstract}

Key words: Medicinal plant, Escherichia coli, resistance gene, molecular detection, multiplex PCR.

\section{INTRODUCTION}

Bacterial food-borne pathogens are the most important food safety issue worldwide. During the past decade, outbreaks of human illness associated with the consumption of fresh fruits and vegetables have increased in the United States (Beuchat, 1996; Brackett, 1999; Blank et al., 2008; CDC, 2008; Berger et al., 2009). The risk of human illness associated with raw produce can be better predicted by monitoring microbial contamination at points of potential contamination in the field during harvesting, during processing and distribution, or in retail markets (Beuchat and Ryu, 1997; Brackett et al., 1993). One major factor that can influence the microbial quality of produce is the type of irrigation used and the water source (Beuchat, 1996; Woodford et al., 2006). For example, cross-contamination from composting farm manure, flooding, and surface run-off 
waters can be sources of pathogenic microorganisms that contaminate fruits and vegetables in the field (Beuchat and Ryu, 1997; Brackett, 1999, Bowen et al., 2006). The presence of enteric human pathogens in the soil may also be largely due to the application of faeces, untreated sewage, or manure either by chance or design. As a result, contamination of fresh produce by fecal coliforms is well documented and recognized as a potential public health problem (Backer et al., 2000; Campbell et al., 2001; Erickson et al., 2007). Several recent outbreaks of Listeria monocytogenes, Escherichia coli O157:H7, and Salmonella spp. have been associated with fresh produce (Backer et al., 2000; Brackett, 2001; Campbell et al., 2001; Itoh et al., 1998). The rapid and accurate identification of bacterial pathogens from food samples is important, both for food quality assurance and to trace outbreaks of bacterial pathogens within the food supply. Growing concerns regarding the safety of fresh produce warrant a greater emphasis on the development of more rapid, specific, and highly sensitive detection methods. Advances in biotechnology have permitted more reliable microbial identification and surveillance (Feng, 1997). Antimicrobial therapy is one of the measures taken to control the diseases caused by E. coli (Blanco et al.,1997), as a result, multi-resistant E. coli isolates may emerge and become a worldwide public health problem, including direct impact on food safety. Antimicrobial resistance determinants are carried mostly by mobile genetic elements such as plasmids, transposons, and integrons (Rowe-Magnus and Maael 2002).

Therefore, fresh or minimally processed vegetables which are often eaten raw or minimally processed, can compromise consumer health safety. The most common bacterial enteropathogens associated with fruits and vegetables are Salmonella spp. (Thunberg et al., 2002) and E. coli O157:H7 (Rangel et al., 2005; Friesema et al., 2008; Pakalniskiene et al., 2009). They are considered among the organisms that are most likely to cause an outbreak and therefore need to be studied for produce safety (Buck et al., 2003). Salmonella is responsible for a localized, self-limiting bacterial infection of the intestinal epithelium, known as "non-typhoid salmonellosis" or "gastroenteritis" and a systemic infection known as "typhoid" or "enteric fever" with severe consequences. The incidence of typhoid salmonellosis is stable, with very few cases in developed countries, but cases of nontyphoid salmonellosis are increasing worldwide (Garci'a del Portillo, 2000). E. coli O157:H7 is the most toxigenic serotype of the genus and is an important cause of diarrhoea, hemorrhagic colitis and haemolytic-uremic syndrome worldwide, associated with high mortality rates of between 10 and 40\% (Palermo et al., 2009). Therefore, the main objective of this study was the molecular detection of the resistance caused by $\beta$ lactamases (blaTEM, blaSHV and blaOXA_1 genes) and the resistance caused by aminoglycoside resistance genes responsible for resistance to gentamicin (aacC2 gene) in resistant $E$. coli isolates recovered from medicinal plants.

\section{MATERIAL AND METHODS}

\section{Bacterial strains}

Eight L-lactamase-producing control strains were used to optimize the PCR assay. These included; E. coli pBR322 (TEM-1producing), E. coli RP4 (TEM-2-encoding), E. coli CF804 (TEM-8expressing), E. coli $\mathrm{RHH}-1$ (TEM- 9-producing), E. coli pUD18 (SHV-3-producing), E. coli (OXA-3-producing; donated by Prof. J. Vila) and E. coli (PSE-3 expressing). In addition, non-L-lactamaseproducing E. coli strains, HB10, were included as negative controls.

\section{Samples}

During the summer of 2010, a total of 204 herbs samples; 34 basil, 40 dry mints, 28 marjoram, 72 chamomile, 22 fennel and 8 calendula flower samples were collected and analyzed for detection and isolation of $E$. coli. Ten negative control field samples were collected from farms continuously monitored for $E$. coli by standard microbiological techniques.

All samples were transported to the laboratory under refrigerated conditions where they were processed and bacteriologically examined immediately.

\section{Isolation and identification of $E$. coli}

Surface technique was used according to modified NMKL, 125 1996 and ISO/FDIS 7218-2007 and membrane filtration method ISO 9308-1, 2000). All samples were primarily cultured on MacConkey agar medium and incubated aerobically at $37^{\circ} \mathrm{C}$. After overnight incubation, a part of single typical well isolated lactose fermenting colonies was tested for sorbitol fermentation by culturing on sorbitol MacConkey agar and sorbitol phenol red agar media and incubated at $37^{\circ} \mathrm{C}$ overnight. Morphological, cultural and biochemical examination were carried out according to methods described by Quinn et al. (2002).

\section{Serotyping of $E$. coli}

Isolates that were primarily identified by biochemical tests were subjected to serological identification using diagnostic polyvalent and monovalent $E$. coli antisera (Welcome $E$. coli diagnostic antisera). Diagnostic E. coli- O157 antisera (Difco code 2970-47-7) and $\mathrm{H} 7$ antisera (Difco code 2159-47-0) were used for serological identification of $E$. coli $\mathrm{O} 157: \mathrm{H} 7$.

\section{Antimicrobial susceptibility test for non beta-lactam drugs}

Antimicrobial susceptibility test to a range of antimicrobial agents was done using disks (ampicillin AMP10, ceftazidime CAZ30, ciprofloxacin CIP5, erythromycin E15, gentamicin CN10, nalidixic acid NA30, oxytetracycline OT30, penicillin G P10, amoxycilinclavulanic acid AMC 30, norfloxacin NOR 10, chloramphenicol C 30, sulphamethoxazole-trimethoprim SXT 25, vancomycin VA 30) and adopting the Kirby-Bauer disk diffusion method using MullerHinton broth and agar and antibiotics disks (Oxoid Limited, Hampshire, England) according to the recommendations of Clinical 
Laboratory Standards Institute (CSLI) formally National Committee for Clinical Laboratory Standards, (NCCLS), 2006.

\section{Resistance gene detection by PCR technique}

PCR was conducted with primers described for the detection of BlaTEM, BlaSHV, BlaOXA_1 and aacC2 genes. The primers sequences and the amplified fragments for the resistance genes are illustrated in Table 1.

Extraction of DNA of E. coli samples by QIAamp DNA Mini Kit (Promega- catalogue number 51304)

The QIAamp DNA Mini Kit provides silica-membrane-based nucleic acid purification from tissues, swabs, CSF, blood, body fluids, or washed cells from urine. The spin-column procedure does not require mechanical homogenization, so total hands-on preparation time was only $20 \mathrm{~min}$. Purification of DNA using the QIAamp DNA Mini Kit can be automated on the QIA cube.

\section{DNA amplification}

Temperature and time conditions of primers during PCR were carried out according to the method of Palermo et al. (2009) and Friesema et al. (2008). PCR amplifications were performed in a final volume of $50 \mu \mathrm{l}$ in micro-amplification tubes (PCR tubes). The reaction mixtures consisted of $5 \mu$ of the DNA template, $5 \mu \mathrm{l} 10 \mathrm{x}$ PCR buffer (75 mM Tris- $\mathrm{HCl}, \mathrm{pH} 9.0,2 \mathrm{mM} \mathrm{MgCl}_{2}, 50 \mathrm{mM} \mathrm{KCl}, 20$ $\left.\mathrm{mM}\left(\mathrm{NH}_{4}\right)_{2} \mathrm{SO}_{4}\right), 1 \mu \mathrm{l}$ dNTPs $(40 \mu \mathrm{M}), 1 \mu \mathrm{l} 1 \mathrm{U}$ Ampli Taq DNA polymerase, $1 \mu \mathrm{l}(25 \mathrm{pmol})$ from the forward and reverse primers of both primer pairs and the volume of the reaction mixture was completed to $50 \mu \mathrm{l}$ using double distilled water (DDW). The thermal cycler was adjusted as follows: Initial denaturation at $94^{\circ} \mathrm{C}$ for 5 min, followed by 35 cycles of (denaturation at $94^{\circ} \mathrm{C}$ for $30 \mathrm{~s}$, annealing at $56^{\circ} \mathrm{C}$ for $\mathrm{s}$, and extension at $72^{\circ} \mathrm{C}$ for $1 \mathrm{~min}$ ). Final extension was carried out at $72^{\circ} \mathrm{C}$ for $10 \mathrm{~min}$ and the PCR products were stored in the thermal cycler at $4^{\circ} \mathrm{C}$ until they were collected.

\section{Agarose gel electrophoresis}

The PCR products were tested for positive amplification by agarose gel electrophoresis as previously reported by Sambrook et al. (1989) using suitable molecular weight markers.

\section{RESULTS}

\section{Standard bacteriological examination of the examined herbal samples}

Fifty-eight (58) strains of E. coli (28.43\%) out of 204 examined herbs samples were isolated and identified by standard microbiological techniques. 24 strains of $E$. coli $(11.76 \%)$ were recovered from Chamomile herpes, while 16 (7.48\%), $10(4.90 \%), 4$ (1.96\%), 2 (0.98\%) and 2 $(0.98 \%)$ strains were recovered from Dry mint, Basil, Calendula flower, Marjoram and Fennel, respectively as shown in Table 2. Serotyping of the recovered E. coli isolates revealed 18 strains out of 58 recovered $E$. coli strains: 0125 (31.03\%), 12 strains were $(20.69 \%)$ O86,
10 strains were $(17.24 \%)$ 0112, 8 strains were $(13.79 \%)$ 0127, 6 strains were (10.34\%) O128 and 4 strains were (6.90\%) O44 as shown in Table 2.

\section{Antimicrobial susceptibility testing}

The 58 herbs strains has resistance pattern against erythromycin, penicillin, amoxicilline clauvenic and vancomycine with a percentage of $100 \%$ and gentamicin, ampicillin, chloramphenicol, oxytetracycline, norfloxacin, trimethoprim and nalidixic acid with percentages of 75.9 $65.5,51.7,48.3,17.2,6.9$ and $6.9 \%$ respectively and non of the herbs strain had resistance against ciprofloxacin and ceftazidime.

\section{Results of Multiplex PCR for detection of $\beta$ - lactamases (blaTEM, blaSHV and blaOXA_1 genes) and single PCR detection of aminoglycoside resistance genes responsible for resistance to gentamicin (aacC2 gene) in resistant $E$. coli isolates}

Multiplex PCR was carried out to detect the resistance genes against ampicillin, amoxicillin clavulanic acid and gentamicine as shown in Table 3 and Figure 1.

A total of $58 \mathrm{E}$. coli isolates recovered by bacteriological examination were tested by PCR for detection of aacC2 gene responsible for the gentamicinresistant. All the isolates showed amplification of $896 \mathrm{bp}$ fragments specific for aacC2 gene as shown in Table 3 and Figure 2. A multiplex PCR was designed to detect BlaTEM, BlaSHV and BlaOXA_1 genes in amoxicillinclavulanic acid and ampicillin resistant $E$. coli isolates. Among the 58 amoxicillin-clavulanic acid and ampicilline resistant isolates, multiplex PCR showed amplification of 516 bp fragments specific for BlaTEM gene in all isolates $(100 \%)$. Moreover, 38 of the E. coli isolate $(65.52 \%)$ had a band compatible with BlaSHV gene (392 bp fragments) while, the presence of BlaOXA_1 gene was not detected in all $E$. coli isolates as shown in Table 3 and Figure 1.

\section{DISCUSSION}

In recent years, the growing consumption of fresh, minimally processed vegetables has lead to an increase in the number of outbreaks of food-borne disease linked to fresh produce (Anon, 2002; Blanck et al., 2008; Berger et al., 2009; Pakalniskiene et al., 2009; Palermo et al., 2009). Agricultural irrigation with wastewater that can be raw, treated and/or partially diluted, is a common practice worldwide and constitutes the main source of pathogen contamination (CDC, 2006; CDC, 2008; Friesema et al., 2008). In the present investigation, 204 herbs samples: 34 basil, 40 drymint, 28 marjoram, 72 chamomile, 22 fennel and 8 calendula flower samples were investigated 
Table 1. The list of primers used in the present study.

\begin{tabular}{|c|c|c|c|c|c|}
\hline Gene & $\begin{array}{l}\text { Primer } \\
\text { name }\end{array}$ & Sequence & Position & $\begin{array}{l}\text { Size of PCR } \\
\text { product (bp) }\end{array}$ & Reference \\
\hline \multirow{2}{*}{ blaSHV } & SHV-F & 5'AGGATTGACTGCCTTTTTTG-3' & $618-636$ & \multirow{2}{*}{392} & \multirow{2}{*}{ Colom et al. (2003) } \\
\hline & SHV-R & 5'-ATTTGCTGATTTCGCTCG-3' & $993-1010$ & & \\
\hline \multirow{2}{*}{ blaTEM } & TEM-C & 5'-ATCAGCAATAAACCAGC-3' & $385-401$ & \multirow{2}{*}{516} & \multirow{2}{*}{ Mabilat and Courvalin (1990) } \\
\hline & TEM-H & 5'-CCCCGAAGAACGTTTTC-3' & $885-901$ & & \\
\hline \multirow{2}{*}{ blaOXA_1 } & OXA-F & 5'-ATATCTCTACTGTTGCATCTCC-3' & $83-104$ & \multirow{2}{*}{619} & \multirow{2}{*}{ Colom et al. (2003) } \\
\hline & OXA-R & 5'-AАACССТTCAAАССАТСС-3' & $685-702$ & & \\
\hline \multirow{2}{*}{ blaOXA_1 } & OXA-G & 5'-TCAACTTTCAAGATCGCA-3' & $211-228$ & \multirow{2}{*}{609} & \multirow{2}{*}{ Speldooren et al. (1998) } \\
\hline & OXA-H & 5'-GTGTGTTTAGAATGGTGA-3' & $803-820$ & & \\
\hline \multirow{2}{*}{ aacC2 } & aacC2-F & 5'-TAG AGG AGA TAT CGC GAT GC-3' & $75-94$ & \multirow{2}{*}{896} & \multirow{2}{*}{$\begin{array}{l}\text { Vanhoof et al. (1992); Vliegenthart } \\
\text { et al. }(1990,1991)\end{array}$} \\
\hline & aacC2-B & 5'-ATT ATC ATT GTC GAC GGC CT-3' & $971-952$ & & \\
\hline
\end{tabular}

Table 2. Serotypes of $E$. coli isolates recovered from the examined herbal samples.

\begin{tabular}{lcccccccccc}
\hline \multirow{2}{*}{ Kind of samples } & \multirow{2}{*}{ Number } & \multicolumn{4}{c}{ Poly 4 antiserum } & \multicolumn{5}{c}{ Poly 3 antiserum } \\
\cline { 3 - 12 } & & $\mathbf{0 8 6}$ & $\mathbf{0 1 1 4}$ & $\mathbf{0 1 2 5}$ & $\mathbf{0 1 2 7}$ & $\mathbf{0 1 2 8}$ & $\mathbf{0 4 4}$ & $\mathbf{0 1 1 2}$ & $\mathbf{0 1 2 4}$ & $\mathbf{0 1 4 2}$ \\
\hline Basil & 10 & 0 & 0 & 0 & 0 & 0 & 4 & 6 & 0 & 0 \\
Dry mint & 16 & 12 & 0 & 0 & 0 & 0 & 0 & 4 & 0 & 0 \\
Marjoram & 2 & 0 & 0 & 0 & 2 & 0 & 0 & 0 & 0 & 0 \\
Chamomile & 24 & 0 & 0 & 18 & 6 & 0 & 0 & 0 & 0 & 0 \\
Fennel & 2 & 0 & 0 & 0 & 0 & 2 & 0 & 0 & 0 & 0 \\
Calendula flower & 4 & 0 & 0 & 0 & 0 & 4 & 0 & 0 & 0 & 0 \\
Total & 58 & 12 & 0 & 18 & 8 & 6 & 4 & 10 & 0 & 0 \\
\hline
\end{tabular}

Table 3. Results of the resistance gene detection among the $E$. coli isolates

\begin{tabular}{|c|c|c|c|c|c|c|c|c|c|}
\hline \multirow{3}{*}{ Samples } & \multirow{3}{*}{$\begin{array}{l}\text { Number of } \\
\text { isolates }\end{array}$} & \multicolumn{4}{|c|}{$\begin{array}{l}\text { Amoxicillin clavulenic acid and } \\
\text { Ampicilline resistance gene }\end{array}$} & \multicolumn{4}{|c|}{$\begin{array}{c}\text { Aminoglycoside resistance genes } \\
\text { (Gentamicin) }\end{array}$} \\
\hline & & \multicolumn{2}{|c|}{ SHV gene } & \multicolumn{2}{|c|}{ TEM gene } & \multicolumn{2}{|c|}{ OXA_1 gene } & \multicolumn{2}{|c|}{ aac2 genes } \\
\hline & & +ve & -ve & $+\mathrm{ve}$ & -ve & $+v e$ & -ve & +ve & $-v e$ \\
\hline Basil & 10 & 0 & 10 & 10 & 0 & 0 & 10 & 10 & 0 \\
\hline Dry mint & 16 & 14 & 2 & 16 & 0 & 0 & 16 & 16 & 0 \\
\hline Marjoram & 2 & 2 & 0 & 2 & 0 & 0 & 2 & 2 & 0 \\
\hline Chamomile & 24 & 20 & 4 & 24 & 0 & 0 & 24 & 24 & 0 \\
\hline Fennel & 2 & 2 & 0 & 2 & 0 & 0 & 2 & 2 & 0 \\
\hline Calendula flower & 4 & 0 & 4 & 4 & 0 & 0 & 4 & 4 & 0 \\
\hline Total & 58 & 38 & 20 & 58 & 0 & 0 & 58 & 58 & 0 \\
\hline
\end{tabular}

bacteriologically to detect and isolate $E$. coli.

As shown in Table 2, 58 strains of E. coli (28.43\%) out of 204 examined herbs samples were isolated and identified by standard microbiological techniques (Palermo et al., 2009). 24 strains of E. coli (11.76\%) were recovered from Chamomile herpes, while $16(7.48 \%), 10$ (4.90\%), $4(1.96 \%), 2(0.98 \%)$ and $2(0.98 \%)$ strains were recovered from Dry mint, Basil, Calendula flower,
Marjoram and Fennel, respectively. These results confirm the results reported by Furlaneto and Mendes (2004) who isolated $E$. coli from herbs and the results indicate that the E. coli levels in basil (Ocimum basilicum) exceeded the regulation levels.

The in vitro sensitivity test of $58 \mathrm{E}$. coli strains isolated from herbs in this study against 13 antibiotics agents revealed that all of the tested strains were highly resistant 


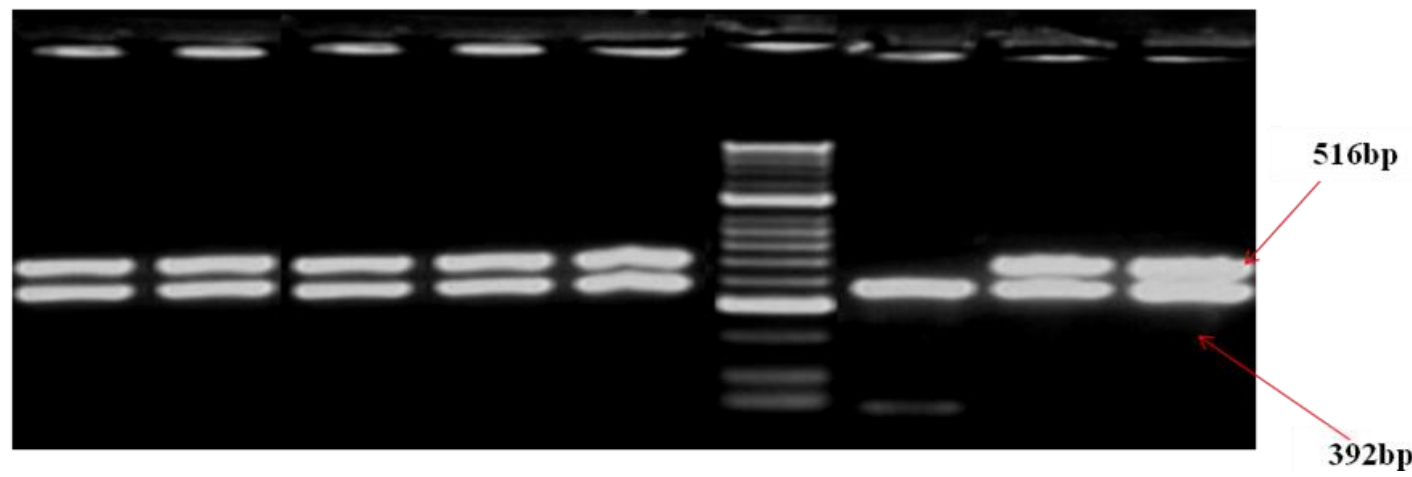

Figure 1. Multiplex PCR showing positive amplification of 516 base fragment specific for BlaTEM gene and 392 base pair fragments specific for BlaTSHV gene.

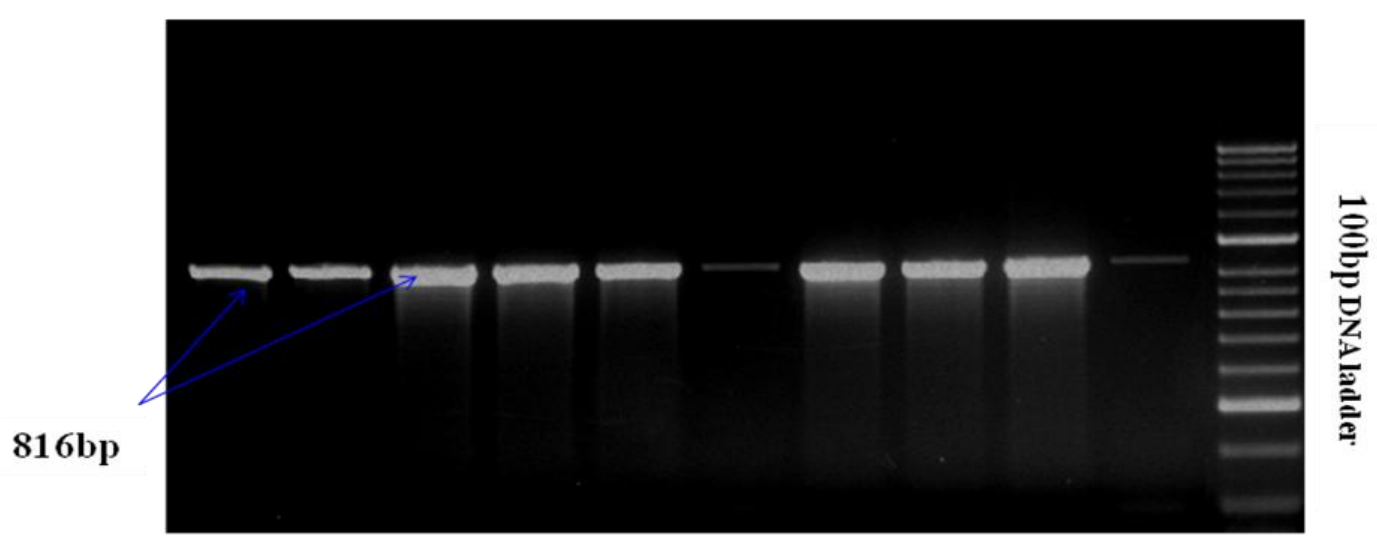

Figure 2. Agarose gel electrophoresis showing amplification of 896 aacC2 gene responsible for the gentamicin resistant.

to penicillin, vancomycine, amoxicillin clauvinic acid and erythromycin with percentage $100 \%$ and this also had been reported by Nazir et al. (2005) who found that all the $E$. coli isolates were found resistant to penicillin $G$ (94.45\%).

These results agrees with those of Wani et al. (2004) who found that the in vitro sensitivity profiles revealed that all isolates were resistant to penicillin and erythromycin which indicated the need for judicious use of antibiotics.

Moreover, most of tested strains were resistance to gentamicin, ampicillin, chloramphenicol, oxytetracycline, norfloxacin, trimethoprim and nalidixic acid with percentage $75.9,65.5,51.7,48.3,17.2,6.9$ and $6.9 \%$ respectively.

Due to the emergence of large numbers of different blaSHV and blaTEM, b-lactamases isoelectrofocusing appears not to be the method of choice for establishing an ESBL phenotype (Hernandez et al., 2005). The solution to this problem has been to characterize ESBLencoding genes using molecular biology techniques with specific primers for blaSHV, blaTEM, and blaCTX-M genes, followed by DNA sequence analysis of the PCR amplicons (Boyd et al., 2004). Recently, multiplex PCR assays for detection of bla-TEM, blaSHV and blaOXA-1 gene have been described (Woodford et al., 2006).

All the $58 \mathrm{E}$. coli isolates recovered by bacteriological examination were tested by PCR for detection of aacC2 gene responsible for the gentamicin-resistant. All the isolates showed amplification of $896 \mathrm{bp}$ fragments specific for aacC2 gene as shown in Table 3 and Figure 2. The obtained results confirm the conclusion of $\mathrm{Ho}$ et al. (2010) who stated that the gentamicin-resistant isolates was PCR positive for the aaC2 gene. Among the 58 amoxicillin-clavulanic acid and ampicillin resistant isolates, multiplex PCR showed amplification of $516 \mathrm{bp}$ fragments specific for BlaTEM gene in all isolates $(100 \%)$. Moreover, 38 of the E. coli isolate $(65.52 \%)$ had a band compatible with BlaSHV gene (392 bp fragments). The predominant resistance genes were: ampicillin, blaTEM1-like and gentamicin aaC2 genes (Guerra et al., 2003).

Therefore, in conclusion, this study show that multiplex PCR is a suitable tool for rapid screening of 
plasmid-encoded L-lactamases which are known to confer amoxicillin-clavulanic acid resistance in E. coli.

\section{ACKNOWLEDGMENT}

The authors extend their appreciation to the Deanship of Scientific Research at King Saud University for funding the work through the research group project No.: RGPVPP-162.

\section{REFERENCES}

Anon (2002). Risk profile on the microbiological contamination of fruits and vegetables eaten raw. Scientific Committee on Food. SCF/CS/FMH/SURF.

Backer HD, Mohle-Boetani JC, Werner SB, Abbott SL, Farrar J, Vugia DJ (2000). High incidence of extra-intestinal infections in a Salmonella havana outbreak associated with alfalfa sprouts. Public Health Rep. 115:339-345.

Beuchat LR (1996). Pathogenic microorganisms associated with fresh produce. J. Food Prot. 59:204-216. Beuchat, L.R., 1999. Survival of enterohemorrhagic Escherichia coli O157:H7 in bovine feces applied to lettuce and the effectiveness of chlorinated water as a disinfectant. J. Food Prot. 62:845-849.

Beuchat LR, Ryu JH (1997). Produce handling and processing practices. Emerg. Infect. Dis. 3:459-465

Berger CN, Shaw RK, Ruiz-Perez F, Nataro JP, Henderson IR, Pallen MJ, Frankel G (2009). Interaction of enteroaggregative Escherichia coli with salad leaves. Environ. Microbiol. Rep. 1:234-239.

Blanck HM, Gillespie C, Kimmons JE, Seymour JD, Serdula MK (2008). Trends in fruit and vegetable consumption among U.S. men and women, 1994-2005. Prev. Chronic Dis. 5: A35.

Bowen A, Fry A, Richards G, Beuchat L (2006). Infections associated with cantaloupe consumption: A public health concern. Epidemiol. Infect. 134:675-685.

Brackett RE (1999). Incidence, contributing factors, and control of bacterial pathogens in produce. Postharv. Biol. Technol. 15:301-311.

Blanco JE, Blanco A, Mora BJ (1997). Prevalence of bacterial resistance to quinolones and other antimicrobials among avian Escherichia coli strains isolated from septicemic and healthy chickens in Spain. J. Clin. Microbiol. 35:2184-2185.

Boyd DA, Tyler S, Christianson S, McGeer A, Muller MP, Willey BM, Bryce E, Gardam M, Nordmann P, Mulvey MR (2004). Complete nucleotide sequence of a 92-kilobase plasmid harbouring the CTX-M15 and the Canadian nosocomial infection surveillance program, Health Canada.

Brackett RE (1999). Incidence, contributing factors and control of bacterial pathogens in produce. Postharv. Biol. Technol. 15:301-311.

Brackett RE, Doyle MP, Beuchat LR, Montville TJ (2001). Fruits, vegetables, and grains. Fundamentals and Frontiers, 2nd ed. ASM Press, Washington, DC, pp. 127-138.

Brackett RE, Horton DA, Fletcher SM, Smallwood D (1993). Food safety: Critical points within the production and distribution system. In: Shewfelt, R.L., Prussia, S.E. (Eds.), Postharvest Handling: A Systems Approach. Academic Press, New York, pp. 301-326.

Buck JW, Walcott RR, Beuchat LR (2003). Recent trends in microbiological safety of fruits and vegetables. Plant Health Progress 1094/PHP-2003-0121-01-RV.

/http://apsnet.org/online/feature/safety/top.asp.

Campbell JV, Mohle-Boetani J, Reporter R, Abbott S, Farrar J, Brandl M, Mandrell R, Werner SB (2001). An outbreak of Salmonella serotype Thompson associated with fresh cilantro. J. Infect. Dis. 183:984-987.

Centers for Disease Control and Prevention (2006). Ongoing multistate outbreak of Escherichia coli serotype O157:H7 infections associated with consumption of fresh spinach - United States, September 2006. MMWR Morb. Mortal. Wkly. Rep. 55:1045-1046.
Centers for Disease Control and Prevention (2008). Outbreak of Salmonella serotype Saintpaul infections associated with multiple raw produce items - United States, 2008. MMWR Morb. Mortal. Wkly. Rep. 57:929-934.

Erickson MC, Doyle MP (2007). Food as a vehicle for transmission of Shiga toxin-producing Escherichia coli. J. Food Prot. 70:2426-2449.

Feng $P$ (1997). Impact of molecular biology on the detection of foodborne pathogens. Mol. Biotechnol. 7:267-278.

Friesema I, Sigmundsdottir G, van der Zwaluw K, Heuvelink A, Schimmer B, de Jager C (2008). An international outbreak of Shiga toxin-producing Escherichia coli 0157 infection due to lettuce, September-October 2007. Euro Surveill. 13:pii=19065.

Furlaneto L, Mendes S (2004). Microbiological analysis of commercialized condiments at free-market and hypermarket." Alimentos-e-Nutricao. 15(2):87-91.

Garci'a Del Portillo F (2000). Molecular and cellular biology of Salmonella pathogenesis. In: Cary, J.W., Linz, J.E., Bhatnagar, D. (Eds.), Molecular Foodborne Diseases. Mechanisms of Pathogenesis and Toxin Synthesis. Technomic Publishing Company, Lancaster, PA, pp. 3-49.

Guerra BE, Junker A, Schroeter R, Helmuth BEC, Guth L, Beutin L (2003). Phenotypic and genotypic characterization of antimicrobial resistance in German Escherichia coli isolates from cattle, swine and poultry. J. Antimicrob. Chemother. 52:489-492

Hernandez JR, Martinez-Martinez L, Canton R, Coque TM, Pasqual A (2005). Nationwide study of Escherichia coli and Klebsiella pneumonia producing extended-spectrum-b-lactamases in Spain. Antimicrob. Agents Chemother. 49:2122-2125.

Ho PL, Wong RC, Stephanie WLO, Chow KH, Wong SS, Que TL (2010). Genetic identity of aminoglycoside-resistance genes in Escherichia coli isolates from human and animal sources. J. Med. Microbiol. 59:702-707.

Itoh Y, Konishi YS, Kasuga F, Iwaki M, Kudo YH, Saito N, Noguchi Y, Konuma H, Kumagai S (1998). Enterohemorrhagic Escherichia coli O157:H7 present in radish sprouts. Appl. Environ. Microbiol. 64:15321535.

Nazir KH, Rahman MB, Nasiruddin KM, Akhtar F, Khan MF, Islam MS (2005). Antibiotic sensitivity of Escherichia coli isolated from water and its relation with plasmid profile analysis. Pak. J. Biol. Sci. 8(11):1610-1613.

Pakalniskiene J, Falkenhorst G, Lisby M, Madsen SB, Olsen KE, Nielsen EM (2009). A foodborne outbreak of enterotoxigenic $E$. coli and Salmonella Anatum infection after a high-school dinner in Denmark, November 2006. Epidemiol. Infect. 137:396-401.

Palermo MS, Exeni RA, Fernandez GC (2009). Hemolytic uremic syndrome: Pathogenesis and update of interventions. Expert Rev. Anti Infect. Ther. 7:697-707.

Quinn PJ, Markey BK, Carter ME, Donnelly WJC, Leonard FC (2002). Veterinary Microbiology and Microbial diseases. Blackwell Scientific Publications, Oxford, London.

Rangel JM, Sparling PH, Crowe C, Griffin PM, Swerdlow DL (2005). Epidemiology of Escherichia coli O157:H7 outbreaks, United States 1982-2002. Emerg. Infect. Dis. 11:603-609.

Rowe-Magnus DA, Maael D (2002). The role of integrons in antibiotic resistance gene capture. Int. J. Med. Microbiol. 292:115-125.

Sambrook J, Fritscgh EF, Meniates M (1989). Molecular Colning: A laboratory manual. Vol. 1. Cold Spring Harbor Laboratory press, New York.

Thunberg RL, Tran TT, Bennett R, Matthews RN, Belay N (2002). Microbial evaluation of selected fresh produce obtained at retail markets. J. Food Prot. 65:677-682.

Toze S (2006). Reuse of effluent water-benefits and risks. Agric. Water Manage. 80(1-3):147-159.

Wani SA, Bhat MA, Samanta I (2004). In vitro drug sensitivity profile and characterization of Escherichia coli isolated from diarrheic chicken in Kashmir valley. Indian J. Anim. Sci. 74(8):818-821.

Woodford N, Fagan EJ, Ellington MJ (2006): Multiplex PCR for rapid detection of genes encoding CTXM extended-spectrum (beta)lactamases. J. Antimicrob. Chemother., 57:154-155. 